Vol.4 No.2

\title{
THE DEVELOPMENT OF FINANCIAL ACCESS (Study Case in South Sulawesi)
}

\section{Retno Andrini , Glenn Nathaniel Pandelaki}

Bank Indonesia

A R T I C LE IN FO

Keywords : Financial access, South Sulawesi

Abstract : The importance of access to finance allows Bank Indonesia to improve financial access for the purpose such as increasing community access and public knowledge to financial services; Providing financial services and products according to the needs of society; Encouraging increased household wealth; Encouraging the growth of the local economy to support the sustainability of national economic growth; and Assist the reduction of the poor. This paper analyze how deep the development of financial access in South Sulawesi. It traces the financial development through the 2010s to the present. Finally, the paper makes an attempt to offer an explanation of development of financial access in South Sulawesi.

Kata Kunci: Akses Keuangan, Sulawesi Selatan

Corresponding author :

Glenn Nathaniel Pandelaki

glennpandelaki@gmail.com
Abstrak : Pentingnya akses keuangan memungkinkan Bank Indonesia untuk meningkatkan akses keuangan untuk tujuan seperti meningkatnya akses masyarakat dan pengetahuan masyarakat terhadap jasa keuangan; Menyediakan jasa keuangan dan produk sesuai dengan kebutuhan masyarakat; Mendorong peningkatan kekayaan rumah tangga; Mendorong pertumbuhan ekonomi lokal untuk mendukung keberlanjutan pertumbuhan ekonomi nasional; dan membantu pengurangan miskin. Karya ini menganalisa seberapa dalam pengembangan akses keuangan di Sulawesi Selatan. Ini menjejaki perkembangan keuangan melalui 2010-an hingga sekarang. Akhirnya, artikel ini menjadi upaya untuk memberikan penjelasan pembangunan akses keuangan di Sulawesi Selatan. 


\section{Background}

\section{INTRODUCTION}

Financial services sector is one important factor in the economy of a region. The existence of banks and financial institutions will sustain the economic activities of the community, as well as facilitate the community to reach the source of capital and in the end the productive sector can be more developed. In Indonesia, the limitations of infrastructure and natural conditions in the form of islands constrain the banks in providing services to communities, especially those located in remote and rural areas. This limitation of banking services is also not separated from the calculation of economies of scale of the bank's operations and the consideration of banks regarding the distribution of population in an area covered by the service of bank branch offices. As a result, there is a disparity in banking services in reaching all government administration areas at both the provincial, district and sub-district levels.

Financial services sector is one important factor as their intermediary function for economy growth, income equality, reducing poverty and financial stability in the economy region. On the other hand, the burgeoning financial industry is not necessarily accompanied by access to adequate finance. In fact, access to financial services is an important requirement of public involvement in the economic system.

Bank Indonesia (2014) notes that about 52 percent of Indonesians live in rural areas and about 60 percent do not have access to formal financial services. Of the approximately 12.49 percent of the population below the poverty line, about 64 percent live in rural areas. These figures, coupled with the geographic distribution conditions of the Indonesian archipelago, point to the importance of an inclusive financial national strategy to pay particular attention to communities in remote areas. The access gap to financial services for this category can be partially overcome by the use of information and communication technologies (e.g mobile money to facilitate transfers and inter-island payment transactions, as well as between rural and urban areas).

Empirically, most of the population in Indonesia has a low ability to access the financial services of banks. In 2014, the percentage of adult population in Indonesia who has account in formal financial institution is only 36\% (source: Global Financial Inclusion Index, World Bank). Although the percentage has increased from the previous Findex results of $20 \%$ (2011), but the figure is still quite low than expected. Then, in accordance with the Bank Indonesia Financial Literacy survey of 2012, only 35.31 percent of Indonesian adult population has been served by banks. This is an indication that people who have no savings at all in the bank or non-bank financial institutions are still relatively high at around 52 percent. The survey results are mutually reinforcing and support that the access of finance to the formal and non-formal financial institutions is still relatively low so that Indonesians with limited access to the financial services system still need to be improved (Bank Indonesia, 2014).

However, among other developing countries, public access to financial services in Indonesia is moderate. The level of access of Indonesians to financial services is greater than two emerging giants India and China, and only slightly below Thailand, Malaysia, and even South Korea. That is, there is still room to make the financial system more inclusive and achieve greater social benefits (BI, 2014). Indonesia itself based on the World Bank survey (2010) ranges from 49 percent of the unserved population, while other countries such as Pakistan, 85 percent of the population have not been served by banking institutions, the Philippines 75 percent, China 60 percent, and India by 55 percent (Prasetyo, 2010, Supartoyo and Kasmiati, 2013).

Nurtjipto (2012) informed that in Indonesia the condition of financial services, services and banking products to 237 million people spread in 253 regencies, 91 municipalities in 33 provinces served by 122 banks with a network of 41,989 Banks consisting of branch offices (KC) ) Of 3,165 offices, 11,135 KCP offices, Cash Office (KK) totaling 4,544 offices, and an ATM machine of 21,415 machines. The number of service networks of commercial banks is still lacking, because 1 network (KC, KCP, KK, and ATM) averages 5,528 people. Moreover there are still many remote areas that are not covered by the banking network. Therefore, in order to extend the reach of financial services, especially to the unbanked and under banked communities, banking infrastructure is taking big role for the availability access for finance. 


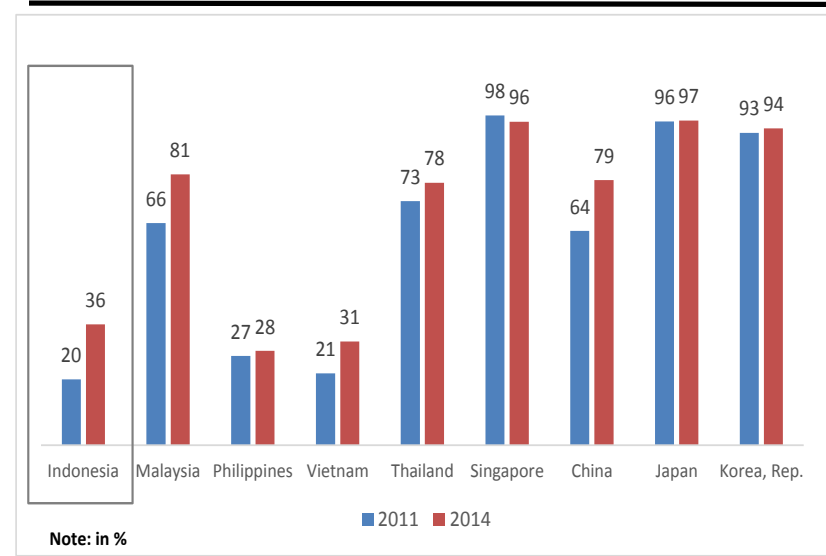

Graph 1. Account at a financial institution (\% age $15+)$

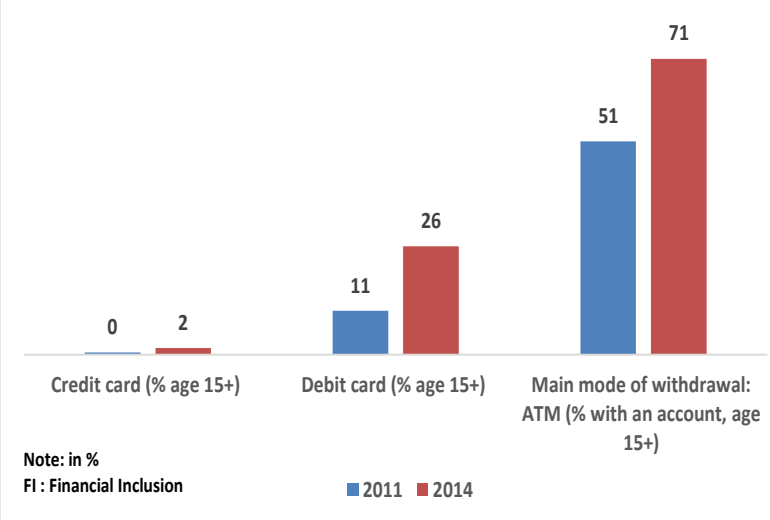

Graph 2. The Development of Financial Access in Indonesia

Source: World Bank

\section{Definition}

\section{THEORITICAL FRAMEWORK}

Financial inclusion is a condition where all of society could reach for financial services easily and optimize banking services as cultural ${ }^{1}$. National strategies for financial inclusion included Perpres No. 82 intended to action plans about economics growth, reducing poverty, inequality among individuals and regions, in order to improve their lives.

As the monetary and Payment System authority, Bank Indonesia has designed the six pillars of policies. There are financial education, financial information mapping, legal framework, intermediation facility, distribution channel, and customers' protection. Basically, it is an effort that drawn up together to abolish the barrier against the poor for enjoying financial services benefits with affordable $\operatorname{cost}^{2}$.

Financial inclusion and access to finance are different issues. Financial inclusion is defined as the proportion of individuals and firms that use financial services. The lack of use doesn't necessarily mean a lack of access. Some people may have access to financial services, but choose not to use it for several reasons like regulatory barriers, legal hurdles and cultural phenomena. Financial inclusion -typically defined as the proportion of individuals and firms that use financial services -has become a subject of considerable interest among policy makers, researchers, and other stakeholders ${ }^{3}$.

Existing literature on financial inclusion has varying definitions of the concepts. Financial inclusion is critical as increasing the poor's access to financial services is often considered as an effective tool that can help reduce poverty and lower income inequality ${ }^{4}$.

Financial inclusion has become one important program of the UN Millennium Development Goals (MDGs). Financial inclusion attempts to open access to financial services for the poor who typically have limited access to financial services5. The World Bank (2010) report only $21 \%$ of Indonesia's population has access to banks and the other $2 \%$ engages in formal non-bank financial services. The fact is that half of the population in most developing countries doesn't have bank accounts. In Indonesia itself it is predicted that around 40 million people don't have any access to financial services. That's because they are living in rural areas with low education, and working in agricultural and services sectors as own workers or as employers assisted by laborers.

\footnotetext{
${ }^{1}$ Jurnal Ekonomi Syariah. Keuangan Inklusif Sebagai Upaya Mensejahterakan Masyarakat (15 Oktober 2016)

${ }^{2}$ Nasution, Lia N \& Handriyani Dwilita. Keuangan Inklusif dan Pertumbuhan Ekonomi Sumut. Jurnal IImiah Research Sains Vol.

2 Nomor 3. September 2016

${ }^{3}$ Global Financial Development Report: Financial Inclusion. 2014

${ }^{4}$ Park, Cyn-Young \& Rogelio V. Mercado, Jr. Financial Inclusion, Poverty, and Income Inequality in Developing Asia. ADB Economics Working Paper Series No. 426. Januarv 2015 
In the contemporary era of running for economic power and self-reliance, it is imperative for any regime to create congenial conditions for individuals, households and private institutions which included the availability of banking services. United nations defined the main goals of inclusive finance as access to a range of financial services, such a saving, credit, insurance, remittance and other banking payment services to all bankable households and enterprise at a reasonable cost. The positive impact of financial inclusion is wide-spread across the globe.

\section{Digital Financial Services}

Financial services are the lifeblood of an economy, enabling households and businesses to save, invest, and protect themselves against risk. Yet in many emerging economies today, the majority of individuals and small businesses lack access to even basic savings and credit products, which hinders economic growth and perpetuates poverty. Most people and small businesses also do not fully participate in the formal financial system. They transact exclusively in cash, have no safe way to save or invest money, and don't have access to credit beyond informal Enders and personal networks.

Digital technologies starting with a mobile phone have the potential to resolve this problem. Digital finance defined as financial services delivered over digital infrastructure like mobile and internet, with low use of cash and other traditional payment systems. Digital finance has the potential to provide access to financial services for 1.6 billion people in emerging economies, more than half of them women, it could increase the volume of loans extended to individuals and businesses by $\$ 2.1$ trillion and allow governments to save $\$ 110$ billion per year by reducing leakage in spending and tax revenue.

Nearly $80 \%$ of adults in emerging economies had a mobile phone, while only $55 \%$ had financial accounts -and mobile phone penetration is growing quickly. Mobile payments can lower the cost of providing financial services by $80-90 \%$, enabling providers to serve lower-income costumers profitability. The data trail these technologies leave can enable lenders to access the creditworthiness of borrowers, and can help businesses better manage their finances.

Banks, telecoms companies, and other providers are already using mobile phones and other readily available technologies to offer basic financial services to customers. Using digital channels can reduce costs of providers and increases convenience for users, opening access to finance for people at all income levels and in far-flung rural areas. For businesses, financial services providers, and governments, digital payments and digital financial services can erase huge inefficiencies and unlock significant productivity gains.

\section{Measure Financial Development}

\section{RESEARCH METHOD}

Methodology used for analyze the development of financial access are descriptive research study. To measure the development of financial access, different sets of indicator have been used. This database has select indicators for the financial access, such as ${ }^{5}$ :

1.Saving account per 1.000 adult

2.Bank branches per $1.000 \mathrm{Km}^{2}$

3. Bank branches per 100.000 adult

4.ATM per $1.000 \mathrm{Km}^{2}$

5.ATM per 100.000 adult

Saving account represent an interest-bearing deposit account held at a bank or another financial institution that provides a modest interest rate. Bank or bank office include branch office and cash office. ATM or Automated Teller Machine is electronic banking outlet, which allows customers to complete basic transactions without the aid of a branch representative or teller. ATM card can do a variety of financial transactions, such as transfer, credit purchase, payment of electricity, payment of subscription products, and so on. In addition, the ATM also has a practical nature, is open 24 hours and rapid (real time) make it easier for people to conduct financial transactions.

\footnotetext{
${ }^{5}$ Background of financial development from World Bank : http://www.worldbank.org/en/publication/gfdr/background/financial-development 119 
ATM can be one solution where people can access finance in the banking and finance could encourage more inclusive.

\section{RESULT AND DISCUSSION}

\section{Financial Development in South Sulawesi}

Table 1 summarizes some select macroeconomic indicators of South Sulawesi economy. The highlights of South Sulawesi's growth story since 2010s the have been:

i. An average GDRP growth rate of 7,85\% achieved over 2010 to 2016, with an increasing share of construction and industry in GDRP.

ii. High GDP growth driven by domestic demand, both consumption and investment.

iii. High average investment rate from $2010-2016$ of $11,76 \%$.

Table 1: Macroeconomic Indicators, South Sulawesi (\%, yoy)

\begin{tabular}{lcc}
\multicolumn{1}{c}{ Indicator } & $\mathbf{2 0 1 1}$ & $\mathbf{2 0 1 6}$ \\
\hline GDP Growth & 8.13 & 7.41 \\
Agriculture & 6.89 & 8.08 \\
Industry & 9.03 & 8.15 \\
Trade and Services & 10.75 & 7.92 \\
& & \\
Domestic saving rate & 2.52 & 1.58 \\
Investment rate & 11.73 & 11.10 \\
Total Foreign Trade & -24.55 & -19.05 \\
\hline
\end{tabular}

Source: Central Bureau of Statistics Indonesia, Bank Indonesia

Although economic growth is slowing down, but the growth of South Sulawesi economy continues to grow high. In sustaining high economic growth, the development of financial access becomes important and has major policy implications.

\section{Development of Infrastructure in Bank}

Bank as financial intermediary should develop infrastructure. Lacking a financial infrastructure that includes a place to save money securely, safe and efficient means of transferring money, and access to credit and insurance, the majority of people on the continent are often barred from making productive investments in their families and businesses.

The development of financial infrastructure in South Sulawesi can be seen from the increasing number of ATM and branch offices. By 2016, the number of ATM reached 3.107 units and the number of bank branches reached 1.061 unit. 


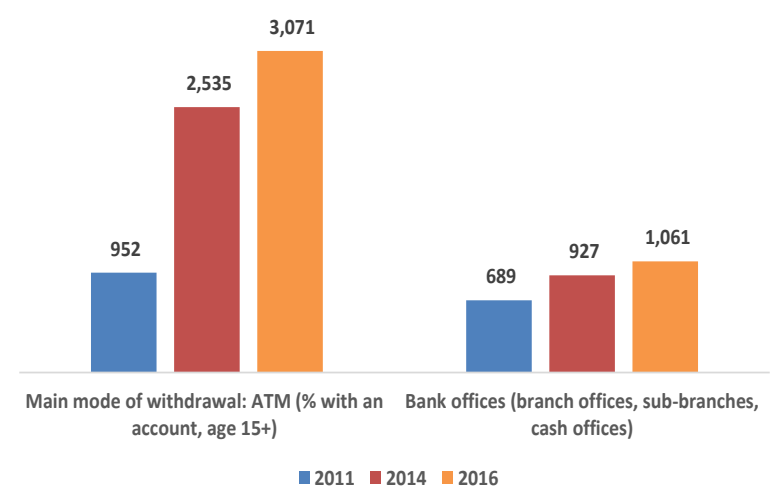

Graph 3. The Development of Financial Access in South Sulawesi Source: Bank Indonesia

\section{Development of Financial Access}

Lack of access to finance is a key constraint on the growth, and thus also an important limitation on employment, economic growth and shared prosperity.

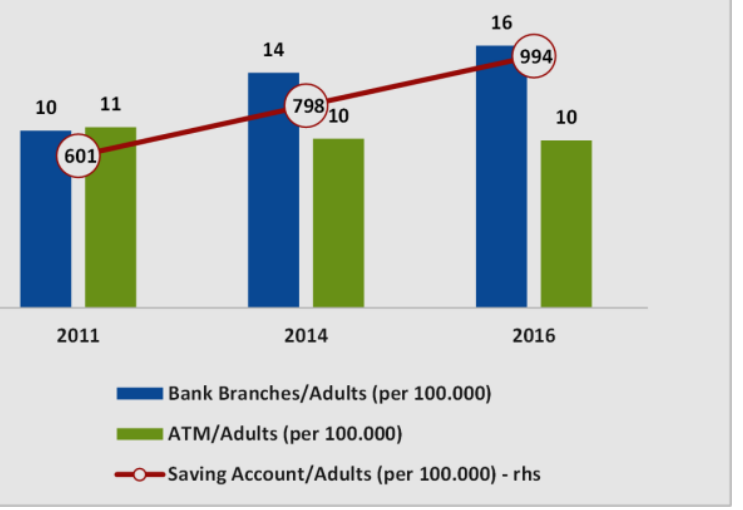

Graph 4. Bank Branches, ATM and Saving account (per 100.000 adults) in South Sulawesi

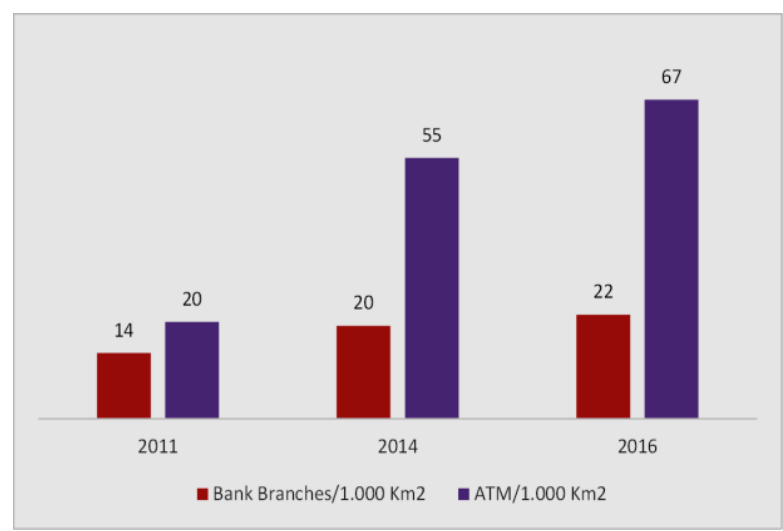

Graph 5. Bank Branches and ATM per 1.000 $\mathrm{Km}^{2}$ in South Sulawesi

Source: Bank Indonesia

By 2016, the ratio bank branches and saving account per 100.000 adults increase, while the ratio ATM per 100.000 adults slightly decrease. Moreover, both ratio of bank branches and ATM per $1.000 \mathrm{~km}^{2}$ increase from 2011 to 2016.

\section{CONCLUSION AND RECOMMENDATION}

The financial access is the key of economic growth. Therefore, Bank Indonesia gives more attention to financial access. Bank Indonesia (2014) mapping to improve access to finance for the purpose of (1) increasing community access to financial services; (2) Providing financial services and products according to the needs of society; (3) Increasing public knowledge about financial services; (4) Encouraging increased household wealth; (5) Encouraging the growth of the local economy to support the sustainability of national economic growth; and (6) Assist the reduction of the poor.

Financial services and banking products in Indonesia spread to 237 million people in 253 regencies, 91 municipalities in 33 provinces served by 122 banks with a network of 41,989 Banks consisting of branch offices $(\mathrm{KC})$ of 3,165 offices, 11,135 KCP offices, Cash Office (KK) totaling 4,544 offices, and an ATM machine of 21,415 machines. Besides that, South Sulawesi as the largest region in Eastern Indonesia noted that the number of ATM reached 3.107 unit and the number of bank branches reached 1.061 unit. Furthermore, by 2016, the ratio bank 
branches and saving account per 100.000 adults increase, while the ratio ATM per 100.000 adults slightly decrease.

Moreover, both ratio of bank branches and ATM per $1.000 \mathrm{~km}^{2}$ increase from 2011 to 2016

\section{REFERENCE}

Bank Indonesia. 2016. Financial Inclusion and Financial stability.

Beta Y. Gitaharie, Lana Soelistianingsih, Triasih Djutaharta. 2014. Financial Inclusion: Household Access to Credit in Indonesia. Working Paper in Economics and Business Vol. IV No. 01. University of Indonesia

Demirguc-Kunt, Asli, Leora Klapper, Dorothe Singer, Peter Van Oudheusden. 2015. The global findex database 2014: Measuring Financial Inclusion around the world. World Bank group.

Global Financial Development Report: Financial Inclusion. 2014. World Bank.

Hanig, Alfred, Stefan Jansen. 2010. Financial Inclusion and Financial Stability: Current Policy Issues. Asian Development Bank Institute.

International Finance Corporation. 2013. Access to Finance: Sub-Sahran Africa. http://www.ifc.org/wps/wcm/connect/e8ea2e004149f9f48008a39e78015671/For+Print+E+FY13+highlights.pdf ?MOD=AJPERES

International Finance Corporation. 2009. Financial infrastructure: Building Access through Transparent and Stabile Financial System. World Bank.

Krishnan, K.P. 2011. Financial Development in Emerging Markets: The Indian Experience. Asian Development Bank Institute.

Jurnal Ekonomi Syariah. 2016. Keuangan Inklusif Sebagai Upaya Mensejahterakan Masyarakat.

Nasution, Lia N \& Handriyani Dwilita. 2016. Keuangan Inklusif dan Pertumbuhan Ekonomi Sumut. Jurnal Ilmiah Research Sains Vol. 2 Nomor 3.

Park, Cyn-Young \& Rogelio V. Mercado, Jr. 2015. Financial Inclusion, Poverty, and Income Inequality in Developing Asia. ADB Economics Working Paper Series No. 426.

Prasad, Ananthakrishnan. Financial Inclusion and Stability: tradeoff and synergies. IMF.

Standard Chartered. 2014. Financial Inclusion: Reaching the unbanked.

Wibowo, Pungky P. 2016. Digital Financial Inclusion (Innovation, Regulation, Ecosystem and Supervision). Bank Indonesia.

\section{Website:}

World Bank : http://www.worldbank.org/en/publication/gfdr/background/financial-development 